\title{
EXPLORING THE CHANGES TOWARDS ACCRUAL ACCOUNTING IN INDONESIAN LOCAL GOVERNMENTS
}

\begin{abstract}
The emerging issue which involves the shift towards business-like system in the public sector, known as the NPM, recently has been discussed much by scholars. Accounting reform as one of the primary agendas within this issue was limited to being addressed in terms of the actual process embedded in the internal organization routine. By utilizing a comparative case study of three departments in the regency level of the Indonesian government, this research aims to explore the process of the introduction of accrual accounting in Indonesia which is facing the sedimented process. The research engages the archetype theory to examine the outcomes achieved by the cases here and a set variable of intra-organizational dynamics. The interviews were organized to obtain the perspective of people involved, combined with textual analysis to clarify the interviewees answer. Radical and incremental outcomes were found, yet consistent patterns in terms of commitment, interest, technical capabilities and managerial capabilities were only associated with radical change. The lack of human resources and the role of the leaders in persuading their staff of the value of reform needs to be reshaped to reach a better outcome.
\end{abstract}

\section{Keywords: NPM, Indonesia, accrual accounting, departments}

\subsection{Background}

\section{INTRODUCTION}

In the last three decades, there has been an emerging phenomenon which entangles the public sector transformation from bureaucratic archetype to the managerial archetype in many countries around the world (Christiaens and van Peteghem, 2007; Mu'am, 2015). This phenomenon is known as New Public Management (NPM). It basically introduces business-like tools and styles into public sector practices (Lane, 2000; Lapsley et al., 2009; Christiaens et al., 2010) and offers a transition from traditional Public Administration into a system which is more efficient, transparent and accountable (Robinson, 1998; Shonhadji, 2010; Hassan, 2015). A number of discussions in the NPM are related to the reform of the accounting systems in the public sector (Guthrie, 1998; Lapsley and Pallot, 2000; Ter Bogt, 2008). Those studies discussed that the reform in accounting systems is not merely related to technical issues but rather the effect of the process in activities.

In Indonesia, the accounting reform was begun by the enactment of new policies related to the shift from cash accounting to accrual accounting in government areas (Harun, 2007; Harun and Kamase, 2012; Hassan, 2013). Significant researches have been conducted to question whether institutions have been implementing a full accrual basis system (Sari and Putra, 2012; Kusuma, 2013; Langelo et al., 2015). Other researchers analysed the challenges faced in the accrual approach (Harun, 2007; Shonhadji, 2010; Ika and Widagdo, 2013; McLeod and Harun, 2014). However, there are still limited studies on the actual process of change in the accounting system in Indonesia (Hassan, 2015). In its process, Indonesia experienced a gradual transition stages through the application of a cash basis, a cash-towards-accrual basis and a full-accrual basis system. Different local governments in Indonesia experienced different ways of responding to the policies which were imposed by 
central government. Given this context, comparative studies regarding the differences in the ways of facing changes and the outcomes reached by each department in Indonesia might give important knowledge to scientists when it comes to the understanding of processes that occur in the introduction of accrual accounting reform.

This study aims to explore more deeply the change processes in relation to the introduction of accrual accounting in department level of the local government in Indonesia. To reach this objective, this study relies on previous measures which have done by Liguori (2012b) that compared the case among single organizations in Italian and Canadian municipalities in the case of disruptive and sedimented process. However, this study examining only the sedimentation scheme within Indonesian cases.

\subsection{Research Approach}

A number of studies employ the institutional theory in approaching the study of accounting changes. This study engages a part of this theory, named the archetype theory to explore the outcomes and a set of intra-organizational dynamics which come from the archetype theory. This approach is a powerful tool in defining and studying accounting change by providing dynamic of the outcomes and the pace of accounting change (Greenwood and Hinings, 1988; Greenwood and Hinings, 1996). Moreover, in term of the research methodology, this research employs a comparative case study for investigating and comparing the cases between departments of local governments in Indonesia with semi-standardized open-ended questions to obtain the perspective of the actors in change processes. This is beneficial in order to analyse the interpretive scheme -i.e. ideas, believes, values- (Greenwood and Hinings, 1996), the outcomes and the dynamics of the change. Furthermore, the textual analysis method is conducted by interpreting official documents such as government regulations, laws, minutes of meetings, disclosures, financial statements and other related documents. The later measure is used for confirming the interviewees answer.

\section{The History Of The Accounting System In Indonesia}

As a country that was colonized by the Dutch for three and a half centuries, the Indonesian government stems from the Dutch colonial system with centralization, top-down administration and autocratic rules (Seymour and Turner, 2002; King, 2003; Harun, 2007; Djamhuri, 2009; Kusuma, 2013; Mir and Sutiyono, 2013). This regulation is guided by the 1864 Dutch Financial Administration Act that is translated in the Indonesian language in Indische Comptabiliteitswet (ICW) Staadsblaad 1925 Number 448 on State Treasury (Harun, 2007; Djamhuri, 2009; Harun et al., 2015; Hassan, 2015). During this time, the cash-basis system for budgeting and reporting became the first accounting system in the public sector accounting in Indonesia (McLeod and Harun, 2014). However, during that time, this policy has been unsuccessful in following the wider range of government financial transaction (The World Bank, 1988; Hassan, 2015). Kristiansen et al. (2009) revealed a serious negative effect from the existing political and bureaucratic tradition on administration procedures such as less control and balances as well as the escalation of corruption (Djamhuri, 2009; Kristiansen et al., 2009; Ika and Widagdo, 2013; Harun et al., 2015)

Consequently, in 1999, for the first time since its independence, Indonesia experienced a big democratic 
reform after the Asia-Pacific Financial Crisis in 1997 and the collapse of the government regime i.e., Suharto regime in 1998 (Harun, 2007; Prasojo and Kurniawan, 2008; Mir and Sutiyono, 2013; McLeod and Harun, 2014). In this reformation era, the new government restored the Indonesian economy and carried out a notable change in many elements of public sector management (Harun, 2007) such as the introduction of a decentralization scheme in political administration (Harun, 2007; Prasojo and Kurniawan 2008; Djamhuri, 2009; McLeod and Harun, 2014). Public sector financial reports which contains public reporting, accrual based accounting and independent audits (Baswedan, 2007) were adopted afterwards.

Furthermore, central government promulgated the Law number 17/2003 and Law number 1/2004 as the foundation to implement the accrual accounting for all levels of government no later than the financial year 2008. In 2004, the Minister of Finance established Public Sector Accounting Committee (KSAP) (Wijaya, 2011) as a specialized institution to prepare the Government Accounting Standards (SAP) in Indonesia resulted in the promulgation of Government Regulation number 24/2005 on Government Accounting Standards. as a transitional step toward a full accrual-based accounting. This regulation introduced the cash-toward-accrual basis which actually is the modified cash basis directed to the accrual basis (Simanjutak, 2005; Amriani, 2014).

By 2010 the full adoption of the accrual basis had not been achieved in all institutions (Sari and Putra, 2012; Hassan, 2015) hence the government issued Government Regulation number 71/2010 on SAP as a substitute for Government Regulation number 24/2005. The point of this regulation is that accrual accounting should be implemented for revenues, expenditures, assets, liabilities, and equity no later than year 2015. With the aim of supporting this regulation, other regulations were also enacted by the related board (Langelo et al., 2015). They were the Minister of Finance Decree number 5/2011 on guidelines to governmental accounting systems and the Minister of Home Affairs Decree number 64/2013 on the application of accrual-based government accounting standards in local governments.

\subsection{NPM Reform}

\section{LITERATURE REVIEW}

Since the late 1980s there were two fundamental inclinations in public sector issue, i.e., 'public sector distinctiveness' and 'rules versus discretion' (Hood, 1995). The first issue represents a demand to minimize or remove the differences between private sector and public sector while the second issue means that the role of public administration needs to be improved in terms of its accountability, effectiveness and efficiency. The NPM paradigm presents the shift from 'bureaucratic model', which focuses on arranging activities based on the available budget and a dependency on cash flow, to become a'business-like professional management model', with the output and outcome orientation (Ter Bogt and Van Helden, 2000; Verhoest et al., 2007; Andrews and Van de Walle, 2013) and a responsibility towards financial position of government (Guthrie, 1998; Wijaya, 2011). Different from the traditional public administration where the government holds some roles specifically to deliver services for its citizens, the new public management scheme sets out a more compound separation of government roles in the economic area as they could be managers or politicians who act, for example, as purchasers, providers, contractors, regulators and umpires (Lane, 2000; Liguori et al., 2009).

In relation to the accounting mechanism, the NPM causes different styles of accounting systems as it 
engages new concepts of accountability and trust patterns (Christiaens et al., 2010; Lapsley et al., 2009; Hood, 1995) and provides substantial measurement tools (Lapsley, 1999) within public sector. Moreover, while accounting plays as an instrument to secure substantive efficiency, it also can be seen as a part of the rationalized rhetoric in the modern public sector system (Lapsley, 1999). Christensen and Yoshimi (2003) stated that the change in the public sector causes in growing attention and argument about performance reports of public sector, especially, concerned to the use of modern technology in accounting reports (Lapsley, 1999). Considering the connection between NPM and accounting practices (Anessi-Pessina et al., 2008; Hood, 1995; Hood, 1991), there is a belief that accounting represents high trust in the market and private business against low trust in public servants and budget-maximizing bureaucrats, therefore it is crucial to evaluate more closely using accounting techniques in their activities.

\subsection{Accounting Reform}

The shift towards accrual accounting was initiated by Australia and New Zealand (Carlin, 2005; Hassan, 2015) then, became a big wave which was experienced by many other countries. The accounting reform faced by many countries was driven by various factors. In the United Kingdom (UK), reform was led by the perceived need of improving information (Ellwood, 2002), while in Canada, Baker and Rennie (2006) revealed that the accrual accounting movement was resulted from the new regulations imposed by the Office of the General Auditor of Canada. Furthermore, the accounting change in Sweden was a part of a broader public sector reform caused by the ideas of 'norm-maker' which followed efficient management system as in the private sector (Paulsson, 2006).

Numerous researches approached the institutional theory (Hyndman and Connolly, 2011; Nor-Aziah and Scapens, 2007; Powell and DiMaggio, 1991) to examine the environmental pressures in the change process. Based on the institutional theory, the change is driven by the organization preferences towards the adoption of specific systems or structures which are valuable in society and cultures (Riberio and Scapens, 2006). In term of reviewing the institutional theory, researchers differentiate between the old institutional economics and the new institutional theory. Pozzoli and Ranucci (2013) summarized that the old institutional economics analyses changes based on the interaction between rules and routines specifically which influence the process of change within the organization. It focuses on coalitions, influences and competing values along with power and informal structures accompanying the reform in accounting system (Burns et al., 1999; Burns and Scapens, 2000). On the other hand, new institutionalism places more emphasis on legitimacy, organizational fields embeddedness, and the centrality of classification, routines, scripts, and scheme (DiMaggio and Powell, 1983; Greenwood and Hinings, 1996). This theory utilizes the observation on environmental pressures which shape the institutions and perceives that accounting reform was led by new regulations, cosmetic behaviour, and the social environment (Nor-Aziah and Scapens, 2007; Pozzoli and Ranucci 2013).

However, the explanation of the accounting reform under the NPM needs to involve both internal and external factors to explain the process of changes (Dillard et al., 2004; Ezzamel et al., 2007; Liguori and Steccolini, 2012). This matter caused the debate to new institutionalism in terms of explaining the practices and ideas which arise from an internal level (Dillard et al., 2004; Ezzamel et al., 2007; Liguori and Steccolini, 
2012). As a result, an archetype theory comes from this perspective since the new institutionalists believe that the idea of design archetypes stem from wider organizational fields (DiMaggio and Powell, 1991; Kirkpatrick and Ackroyd, 2003).

\subsection{Archetype Theory in Explaining the Change}

Greenwood and Hinings (1993) formulated the concept of archetype from the holistic perspective of understanding organizational systems and the interpretive scheme. They defined that an archetype is a set of structures and systems which represents a single interpretive scheme -ideas, beliefs and values- embodying organizational structures and system (Greenwood and Hinings, 1993). Drawing from this concept, Brock (2006) extrapolated that the structure and system are not an organization disembodied frame but are rather infused with meanings, intents, preferences and values. By using this perspective, the challenge to achieve successful changes requires an alternative interpretive scheme (Brock, 2006). According to Greenwood and Hinings (1993), the interpretive scheme is not static and unchanged, rather it is dynamic. Besides, the organization structures and system together with their embodying ideas, beliefs, and values have a reflexive relationship which influences the pattern of change (Brock, 2006).

Changes can be defined as the shift of an old archetype to a new archetype (Greenwood and Hinings, 1993). In the case of NPM reform, the agenda of a new managerial system is a new archetype against the old one which is the traditional bureaucratic archetype (Liguori, 2012b; Liguori and Steccolini, 2012). Given that the market environment is one of the pressures of the strategic management reform (Greenwood and Hinings, 1996; Pinnington and Morris, 2003; Dillard et al., 2004), some studies revealed that the existing archetype can be used to demonstrate recent and ongoing environmental pressures. Besides, the archetype theory is a powerful tool to understand the outcome (Greenwood and Hinings, 1988; Greenwood and Hinings, 1996) which could be radical or incremental. Defined by Greenwood and Hinings (1996), the radical outcome involves changes in structures and systems as well as interpretive schemes, while the incremental outcome only modifies the shift of structures and systems change. Additionally, Liguori (2012b) in her study proposed the terms of 'no-change' as a new concept of outcome which shows more than incremental changes. By using the framework of archetype, it is possible to determine whether organizations achieve radical or incremental outcomes (Liguori, 2012b).

The process of reform can be defined as a sedimented process (Malhotra and Hinings, 2005) that means that the alternative new idea exists by layering the old structures, systems, and beliefs. In this scheme, arguably, the radical change is associated with a gradual and stages shift of change processes. Given that radical change is defined as a fundamental change to an original idea which, by default, transforms the overall structure, system and the interpretive scheme of process (Liguori, 2012b), it is crucial to be well prepared to accommodate this change. Otherwise, radical changes on a wider scale that are not accompanied by a continuum of commitment and preparation will be difficult to be achieved.

Accounting changes engage both external and internal pressures of the organization (Hinings and Greenwood, 1988; Ter Bogt and Van Helden, 2000). While new laws or cosmetic behaviors (Tsamenyi et al., 2006; 
Collier, 2001; Nor-Aziah and Scapens, 2007) represent the exogenous factors, the condition and interaction (Ter Bogt and van Helden, 2000) among members within the organization which involve interests, values, power dependencies, and capacity for action (Greenwood and Hinings, 1996) represent the endogenous drivers which shape the processes and the outcomes of change. Accordingly, it is necessary to study the changes in terms of the organizational context and intra-organizational dynamics (Hinings and Greenwood, 1988; Greenwood and Hinings, 1996).

Since the Archetype theory was designed in order to cover the gap between old and new institutionalism, Liguori (2012b) considered that, in addition to internal dynamics, contextual disruption (e.g., external pressures) stimulated organization response to change. While micro-processes within organizations directly affect the outcome of change, environmental pressures are helpful in explaining the reason why some organizations achieve radical change and others do not even face the same institutional pressures. The environmental factors provoke the need for reform by the actors interpretation towards new ideas and belief in better systems, therefore, these weaken the existing archetype (Oliver, 1991; Kirkpatrick and Ackryod, 2003). Organizations might experience similarity when they arrange legitimacy based on environmental factors.

\subsection{Intra-organizational dynamics underpinning reform}

As the actors in the reform are able to use their power and capability, it is possible for them to benefit the organization as a mean to reach their goals. Interaction among the actors within the organization, thus, could impact on the actor responses towards the pressures to change (Ter Bogt and Van Helden, 2000). It means that the micro-processes which occurred within the organization have an important role to determine the interpretation of the organization responses (Liguori, 2012b) and need to be taken into account to get a better understanding of the change processes (Hinings and Greenwood, 1988; Greenwood and Hinings, 1996). By understanding the dynamics of the change processes (Burns, 2000), the actors were able to mitigate against potential problems along the way. Therefore, intra-organizational dynamics play an important role in forming the perspective of the actors towards the changes.

Based on the archetype approach designed by Greenwood and Hinings (1996), precipitating dynamics consist of 'interest' and 'value commitment'. The 'interest' aspect relates to different group dissatisfaction (Greenwood and Hinings, 1996) towards the existing template of organization. Alternatively, 'interest' is defined as the perspective of actors, whether they are happy or unhappy, regarding the existing and the new systems (Lukas, 1974). In associated to 'interest' aspect to result radical change, 'value commitment' is coupled as precipitators. The later aspect relates to the connection between the prevailing template in terms of 'what and how' an action needs to be taken and judged by organization (Hinings and Greenwood, 1988; Greenwood and Hinings, 1996).

Furthermore, Greenwood and Hinings (1996) also developed the enabling dynamics which consist of 'power dependency' and 'capacity for action' or 'capability' in another word. In terms of 'power dependency', radical change requires power resources to encourage preferences and interests to favor the new system (McNulty and Ferlie, 2004). This is drawn from the concept of the power by certain groups that have influential 
positions in decision making in a favorable organizational setting (Pfeffer, 1981). Finally, the last aspect of intra-organizational dynamics is 'capacity for action'. This is formed by a combination of technical matter and managerial capabilities. Technical capabilities refer to deep knowledge of new schemes, skills and competencies to shape new agendas which can be classified as high or low knowledge and skill and concentrated or dispersed capabilities, while managerial capabilities refers to the leadership style (i.e., transformational versus transactional and substantive versus symbolic) to reach the final outcome of change.

Previous research on the changes in accounting systems found that the organizational capacity, which related to intra-organizational sources has impacted on different outcomes at the level of implementing the accrual approach within local government (Ter Bogt, 2008; Liguori and Steccolini, 2012; Bruns, 2014). Although the new regulation was mandatory, the actors in public sector accounting could either change or allow inertia in terms of values and beliefs of the accrual system (Ma and Tayles, 2009; Malsch and Grendon, 2013). Besides, according to Malsch and Grendon (2013) studying public sector accounting reform would be appropriate to emphasize the power and capacity which stimulate the reform. Others studies more concerned on the actor interest since the existing accounting routines were likely to persist as they were already adhered to in organizational activities (Burns and Scapens, 2000; Ma and Tayles, 2009). More specifically, Liguori (2012b) which interprets the dynamic within organizations and various outcomes in managerial and accounting change found that interest satisfaction and transformational and symbolic leadership factors need to be addressed more in the radical accounting reform processes in Italian and Canadian municipalities. Meanwhile, empirical research shows that power dependencies, leadership capabilities and technical capabilities work as a knowledge basis and are beneficial to espouse change. Moreover, in this research as well Liguori (2012b) met a blurred composition of intra-organizational dynamic elements which linked to incremental and no-change outcomes.

\section{RESEARCH METHOD \\ 4.1. Ontological and Epistemological Assumptions, Approach and Purpose}

The method that is used here follows that has done by Liguori (2012b) which is a comparative case study method. This method is an appropriate method to investigate the character of a person or institution in solving problems and to gain more factual observations about the factors that would influence the success or failure of an existing phenomenon (Yin, 2003; Burton, 2000). The cases between departments of local governments, specifically in regency/city level in Indonesia, in response to changes in the rules on the basis of accounting in financial reporting are chosen for exploration in this research. Given that Indonesian government currently is facing the issue of accrual accounting reform (Harun, 2007; Harun and Kamase, 2012), study in this field is a relatively new and interesting to be discussed.

In accordance with the objectives of this research, this qualitative research provides the useful in-depth and exploratory means to reach a clear explanation of the phenomenon (Symon and Cassel, 1998). Some scholars stated that in an organizational field, qualitative research provides a robust foundation to analyse and interpret a phenomenon because it is based on the natural environment (Collis, et al., 2003). This type of research generally is presented in the form of text and involves textual resources such as interview transcriptions 
or organizational documents; however, it may also include non-textual data such as tables, pictures, audio and video recordings (Patton, 2002; Strauss and Corbin, 1998).

In qualitative research, regarding the implementation of policies in an organization, Ritchie and Spencer (2002) classified some techniques of analysis: Contextual, Diagnostic, Evaluative and Strategic methods. The two former methods (i.e., contextual and diagnostic) are used in this study to identify the shape and nature of the phenomenon and to examine the causes of the phenomenon. The contextual method is a technique for understanding a theory by connecting it to the facts and the diagnostic method is a method that contains several ways to achieve the most relevant results (Ritchie and Spencer, 2002). Therefore, the contextual method is used here for connecting theories underpinning the accounting reform to the real phenomenon in Indonesian local government, while the diagnostic method is used here since this study gathers the outcomes and intra-organizational dynamics to obtain reasonable and directed results of the accounting reform process. Moreover, to identify the perspective of the actors, this research conducts an interview with the key informants from each department, such as the heads of department and finance managers. Snowball sampling (Patton, 2002) is adopted as well in this research to capture the interviewees. Also, this research is conducted by the interpretive literature study method to support the result of the interviews. The relevant published documents are used as the sources of secondary data in this research.

\subsection{Case Selection}

Patton (2001) provides a number of strategies in choosing samples for case study research which could be used by researchers to formulate which case has the most suitable information for analysis. This study follows one of the strategies by Patton (2001) which is the Stratified Purposeful Sampling as the chosen cases in this study have to meet some characteristics which are relevant to fulfil the aims of the research and they are filtered within a broader sample or, in other words, samples are taken within samples. In this case, government institutions at cities/regencies level are the representative of local government. The criteria to determine the sample in this study is based on organizational size and geographical location. Only big regencies based on a total population of over two million are used here and both regencies are comparable since they are located in similar geographical conditions. Therefore, the 'Egg' and 'Onion' regencies ${ }^{(1)}$ were selected for this study.

Furthermore, the comparison of the cases between single governmental departments in selected regencies was conducted. The method for choosing departments here is using maximum variation sampling (Patton, 2002). This method is appropriate to obtain the heterogeneity in order to understand how accounting reform is seen and understood among different actors in different institutional settings. Following the type of departments chosen by Liguori (2012b), this research selected the social services, environment, and public infrastructures departments. Liguori (2012b) identified departments based on their level of output measurability and discovered that the departments of public infrastructures, environment, and social structures consecutively ranked the highest service output measurability based on Brown and Potosky (2003). Meanwhile, based on the official website of both regencies, this study additionally observed that the selected departments provide the most positive impact on public sector flexibility and the opportunity for economic

Jurnal Akuntansi Indonesia 
structure development in both Egg and Onion regencies. Therefore, these three departments were chosen here, giving a total of six cases to be examined.

\subsection{Data Collection}

The introduction of the accrual accounting in Indonesia has been taking place since 2003, when the law was launched. However, the report of local governments published by the State Audit Board in 2015 shows that the planned goal of the government had not been achieved. As aforementioned, the planned change of structures and elements in the financial statements presentation should have commenced after the law in 2005 was enacted and the use of full accrual basis should have been achieved no later than 2015, thus, this research analyses the process of reform during 2006-2015. Over those periods, the classification issues in local government are divided by the last implementation of cash basis; the implementation of cash-towards-accrual basis; and the movement in accrual basis.

As this research analyses the process of change which involves the actors who play a role in the changes, the interviews are conducted in the selected departments in Egg and Onion regencies. There is the total of 12 interviewees consist of the head of department and finance manager from each department. Snowball sampling (Patton, 2002) is applied to capture the second participant that is the finance manager of each department based on the recommendation from the head of department as the first participant. Moreover, the participants have to meet the criteria that they are involved in financial decision-making and also have been working with the department during transition period of accounting system (2006-now). These are considered to obtain the eligible participants to be interviewed as they play a role in making decision, know the history of the transform processes and understand the current situation of the accrual accounting implementation in their department.

The topic of questions here involves the practice of new accounting systems in the change process and the respondent perspective towards the value, beliefs, and ideas before and after the change is proposed. In addition, since this research relied specifically on the archetype theory and intra-organizational dynamics, the question topic also includes the outcome of the change (radical or incremental) as well as four variables of intra-organizational dynamic (value commitment, interest, power dependency and capabilities).

After the interview was completed, the results were transcribed, interpreted and combined with the results of document analysis. The collected documents were secondary data which consisted of: the archival financial report; regulations; statutes; online news; the audit report and other relevant documents that all of which are official and publicly available on the government's official website. This data examination is beneficial in order to gain more information and valid data combined with to the respondents answer in interviews.

\subsection{Data Analysis}

The diversion from cash basis to accrual accounting is expected to provide advantages that are more efficient, transparent and accountable, but many factors are needed to support the success of change. In Liguori (2012b) it is mentioned that the dynamics related to the process and pattern of accounting change were explained by precipitators (interest and value commitment) and enablers (power dependency and 
capabilities) in the light of the archetype theory. Thus, those drivers were analysed through the collected data in this research.

In order to analyse the collected data, the interview results are interpreted here by the assessment criteria which follow Liguori (2012b). The value commitment pattern consists of status quo (for the preference towards the existing archetype), indifferent (when groups neither commit nor oppose the new ideas), competitive (when some support the alternative archetype and others are more comfortable with the used system) and reformative (for the preference towards the alternative system). These patterns were found based on the interviewees agreement towards the values of the new system against the previous system. Their answers were used to indicate whether they are willing to carry out the new policy. Furthermore, the interest patterns are classified on satisfaction and dissatisfaction with the alternative ideas. This assessment is obtained from the actors feelings in implementing accrual accounting.

Dispersed versus concentrated power was measured from the interviewee's position and function within the departmental hierarchy as well as by how the decisions are made in the department. Dispersed power is depicted as a widespread distribution of the information and decision-makers, while concentrated power exists if only a few parties hold the authority for resources and decision-making processes. Regarding the technical capabilities patterns, high versus low capabilities, are grouped together with dispersed versus concentrated capabilities. These are assessed based on their knowledge of the accrual accounting procedure, the use of tools in accounting operations, and the responses towards the training provided. Proficiency and fluency in explaining financial procedures in the accrual basis, enthusiasm for training, and the diffusion in using software by staff indicates high and dispersed capabilities, otherwise it is considered to be low and concentrated capabilities. Lastly, the managerial capabilities pattern was identified by whether the leaders have transformational or transactional leadership with symbolic or substantial capabilities based on the way they bring their department along with them to implement the new policy. Leadership is symbolic when the leader is responsible to the organization as a formal obligation while it is substantive if the leader contributes more in distributing values and strategies to direct the implementation of accrual accounting. Moreover, transactional leadership exists with basic and general knowledge to comply with the regulations while transformational leadership occurs alongside a deeper sense of shaping skills, culture, and competencies.

In order to develop the examination, the collected documents were interpreted. In terms of analysing the commitment and tendency of the actors to implement the existing rules, the statutes and regulations were compared with the meeting minutes and media reports in related issues. Finally, strength and capabilities were analysed in this study through financial and budgeting reports, meeting notes and the archived activities agenda which provided information on the organization flow; how often they updated their working equipment and facilitated training for new standards; as well as the successes of new plans.

\subsection{The Accounting Reform Processes in Indonesia}

\section{FINDINGS AND DISCUSSION}

The history of the reform in accounting basis in Indonesia has been detailed earlier in this research. Accordingly, significant reform of the accounting systems in Indonesian government started in 2003. The 
government adhered to the Dutch colonial system that is ICW as the basis for the application of public administration systems, including the accounting records, since the independence of Indonesia. In 2003, the NPM waves which were endured by many countries inspired Indonesian government to follow the ideas and practices of the private sector and apply them to the activities within the government area. Changes in the accounting system were derived from the centralized rules set up by central government which were to be deployed across all government levels (i.e., State-owned and Regional-owned enterprises).

Changes in Indonesian local government occurred slowly and sedimented as they did not immediately happened, but step-by-step schemes were needed to achieve the full implementation of accrual basis. Based on the Government Regulation number 71/2010 article 7, it is stated that the implementation of accrual basis is carried out in stages from the implementation of cash-towards-accrual basis to the full accrual basis implementation. Alongside, the implementation of cash-towards-accrual basis for them which have not been ready to evolve in $\mathbf{2 0 1 0}$ was allowed until the further policy enacted. Therefore, while new systems have been attempted, the old one were used as well in the same period; given the alternative archetype exists accompanied the old one among the government institution in transition period. This phenomenon occurred during the observation period and was confirmed by interviewees when they were asked about the chronology of the accounting system changes, such as the statement below by one of the interviewees.

Some earlier laws were established regarding the introduction of the accrual basis, but we just implemented it in 2015. Previously, from 2010, we still used the transition basis, namely the cash-towards-accrual basis. (Egg Regency Public Infrastructure 1)

Regarding the governmental structure, Indonesia has 5 levels of government, namely a central government which is chaired by a president, and local governments that consists of 34 provinces headed by governors, 514 cities/regencies led by the mayors/regents, over 7,000 districts led by the head of the district and 80000 sub-districts led by headmen. According to Law number 25/2009 on Public Service, both central and local governments are responsible for the service delivery of public goods and services as well as administrative services. In addition, each local government also has the authority to propose draft of local regulations and to raise taxes. However, the highest legislative authority of law related to state administration including financial reporting system only held by the central government.

Related to the accounting system used by the government, the arrangement of cash-towards-accrual basis as the transition stages helps the local government to customize the report preparation to be accrual. In this method, referring to the guidance for Government Regulation number 24/2005 some recording routines that were previously used on the cash basis are still applied, coupled with the recognition of accounts receivable, fixed assets, and debts posts which were then used to prepare the balance sheet on cash-towards-accrual system. The use of debt and receivable posts are as a counterpoint on income which has not been received and expenditure which has not been paid. Furthermore, in the implementation of the accrual basis, the local governments have to allocate asset depreciation to provide information of the expenses on asset consumed in a period. This will contribute to the accurate charges for services provided during the period. The empirical evidences of the above process were obtained from statements below, which are the interviewees answers 
when they were asked regarding the differences between cash and accrual accounting procedure.

In the past, before change was imposed, we only presented the budget realization report that we recorded based on the money that comes in and out in our operations, then central government instructed us to draw up the balance sheet by recognizing revenues and expenditures that have not happened and allocate the depreciation of assets, and we also should draw up a report of operations and changes in equity. After this we do not know what more will be added for us to execute. (Egg Regency Public Infrastructure 2)

We classify the data to be inputted based on the Minister Regulation and the government accounting standards (SAP) to compose the budget realization report, balance sheet, changes in equity statement, operational report and notes to financial statements. Cash flow is only held by the department of local financial management as local treasurer agency by collecting data from all other departments based on the budget report. (Egg Regency Environment 1)

With regard to the technical system in applying the accrual accounting, the central government also provides an integrated application as part of 'the IT project' to be used by all government agencies (Analyst Bureau of Budgetary, 2015). The project includes the development of supporting applications i.e., Treasury and the State Budgeting System (SPAN) application, Application Systems for Financial Institutions (SAKTI), and Accrual Based Accounting System for Agencies (SAIBA). The SPAN application was designed by using the Commercial off the Shelf (CotS) i.e., Oracle Finance system that provides the option of using the cash basis or accrual basis. This application integrates budgeting process, implementation, and financial reporting by using the single database. Additionally, SPAN was designed considering software, hardware, human resources, procedures, controls, and data as well as fully automated operation and comes down to a centralized database. Meanwhile, SAKTI is an application that is built to support the implementation of SPAN on the level of local government departments and SAIBA is an application for the adoption of accrual-based SAP in local government. A set of these applications is referred to as the Regional Financial Management Information System (SIPKD). The used of this software are confirmed here by the interviewees:

That was great as we got the application for our work. Using SIPKD (Regional Financial Management Information System) we can integrate the process of implementation and accountability in accordance with the budget cycle directly with the finance ministry. This change is not too difficult for us and the value of our performance can increasingly be seen more clearly. (Onion Regency Environment 2)

However, although standards have been established and facilities have been provided by central government, up to the expiry period for using the cash-towards-accrual basis in 2014 , there were still a lot of adjustment processes must be carried out by local governments since most of the participants suggested about the need of adjusting strategy to implement the accrual accounting as the statement below:

We have not been able to measure the percentage of our achievement yet because there are still many things that need to be adjusted. To be sure, this achievement in the implementation of a full accrual basis has not been perfect. This process is still long. (Onion Regency Public Infrastructure 1) 


\subsection{The Outcome of Changes}

Based on the observations of the six cases studied, only two departments can be said to experience a radical change, they were Onion Regency Environment and Social Services. The leaders of Onion Regency Environment were aware that the weaknesses in their department to comply with the regulation number $71 / 2010$ were associated with competent human resources. Therefore, since the announcement of the Minister of Home Affairs Decree number 64/2013 on the Application of Accrual Based Accounting in Local Government, various agendas were undertaken to introduce and improve the quality of knowledge regarding new accounting standards. Besides, the staff were also involved in the effort to increase their quality. Similarly, Onion Regency Social Services also carried out several efforts to increase the quality in presenting their financial statement and realized that the financial management is fundamental to assess the success of the department. Given the above statements, it is could be concluded that both department were changing, complying with the proposed regulations as well as their belief and idea. This shows the existence of radical change which is defined as the change that not only happens within systems and structures, but also the way it is interpreted by the actors.

However, the other four departments only change technically but not in values and beliefs given that the incremental change occurred in these departments. In Egg Regency Public Infrastructure, for instance, the finance manager felt that there was no additional value in this new idea. The things which he did to the department were only to meet the existing regulations. Performance in the financial statements did not the most important thing in department routines because primarily the public will complain if they are unable to arrange and deliver a good infrastructure. It is more important for the infrastructure department performances. Changes towards the accrual basis create a greater workload as it is difficult and requires a long time to implement. In Egg Regency Environment, the adoption of the accrual basis is held to comply with the central government regulation. The financial employees feel this change is a problem for them because they are used to working with the old system.

\subsection{Assessing the intra-organization dynamic to explain the change processes}

Intra-organizational dynamics are a set of aspects which are useful in constructing the change. The heterogeneity in the outcome of change among different organizations can be caused by different patterns of daily routine and culture within organizations. As sedimentation happened in terms of accounting basis reforms in Indonesia, specific patterns of internal dynamics were found in radical outcome except in the pattern of power factors. Onion Regency Environment and Social Services Departments met the satisfaction of their staff and leader with regard to the introduction of accrual accounting as a new archetype. Besides, reformative commitment was also found since they were happy and enthusiastic with the new archetype.

Given their responsibility as leaders, managers constantly motivate their staff and inculcate the values of a rule to all staff in both Onion Regency Social Services and Environment. This indicates that transformational and symbolic leadership exists in radical change. When there was important information, including new instructions from central government, the head of department in Onion Regency Environment, always emphasized it in his 
speech in the morning ceremony.

In Onion Regency Social Service, every strategy to improve staff understanding to comply with the policy was conducted. However, there were unclear patterns in term of technical capabilities both in Onion Regency Environment and Social Services. Even though staff were eager to learn and get involves in every course provided, they still felt difficulties in understanding the accrual accounting since many of their staff are not from accounting background in terms of their educational background. Besides, Onion Regency Social Services felt that they are only the passive users in operating the application system so that they are confused about their capability in IT development. Inconsistent patterns in power dependencies were found in radical change for these departments. Onion Regency Social Services dealt with concentrated authority, while in Onion Regency Environment the changes were corroborated by widespread power hold by most of the parties including staff.

Differently, in other four departments which only reach an incremental outcome, vague patterns appear on their configuration of intra-organizational dynamics. Inconsistent structures of precipitator and enabler variables across the organization were found. However, all of the cases demonstrated the concentrated power and the symbolic leadership. All the interviewees, when it comes to the question of authority, expressly emphasized that there is not much which staff could do except accepting the rules and their duties. The managers as parts in decision-making also could not do anything when the department head gives an instruction.

The interest aspect met dissatisfaction with the new archetype in Egg Regency Public infrastructure and Environment. The justification for sating that they do not prefer the alternative archetype is drawn from their judgment about cash accounting which is simpler to practice. Meanwhile, neither satisfaction nor dissatisfaction ware found in the remaining cases since they stated an ambiguity in their feelings in agreeing the need for the new archetype.

No specific pattern appeared regarding commitment and technical capabilities appeared in most cases while indifferent and status quo commitment happened in Egg Regency environment an Onion Regency Public Infrastructure respectively.

Together with the symbolic patterns as managers did their duty in organization formally, transformational leadership is owned by managers in the Egg Regency Public Infrastructures and Environment. However, they have not been succeeding in determining the value and beliefs of the alternative archetype to the whole part of department, given that they have not been able to achieve the radical change. Transactional and symbolic leadership exists in Egg Regency Social Services and Onion Regency Public Infrastructure. The table 1 below summarize the findings of the outcome of change as well as the intra-organizational pattern of six cases.

\section{CONCLUSION}

This research engages both the intra-organizational dynamic and the archetype theory to define the dynamic interpretation of the outcomes and the processes in accounting change. While interviews were carried out to obtain the perspective of people who were involved in the change processes, textual analysis was utilized to double check and to confirm the interviewees answers. There are two types of outcomes were 
found in the Indonesian regencies' governments in this study which are radical and incremental. Regarding the process of change, the configuration of intra-organizational dynamics shows consistent patterns in terms of commitment, interest, technical capabilities and managerial capabilities associated with radical change.

Power dependency factors here even plays a crucial role in determining the outcome of change, yet either dispersed or concentrated have its strengths and weaknesses in each department. As a result, this factor needs to be combined with other aspects. Value commitment that is, based on managers' observations, inferred from the attitude of staff in judging the benefits of a new policy was the most important factor in creating radical change. It is because when they understand the benefits obtained in the implementation of accrual accounting to their performance, they will understand the necessity of applying these bases and gain satisfaction from the performance of the new system. This then results in a willingness to implement changes. Their enthusiasm for the change is the first step to enhance their ability to create an intact change.

Interest satisfaction is also a key to the success of change because the actors' willingness to accept the new archetype provides great support while their reluctance for change inhibits the change. Power dependences could be the primary support in the change of structures and systems, however, this does not really influenced in radical change since in a particular case radical change was associated with either dispersed or concentrated. Meanwhile, transformational and symbolic leadership seems demanded in radical change even in incremental changes, some cases this pattern was also emerge. With regard to technical capabilities, sedimented process is not essentially congruent in achieving the full adoption of accrual accounting. As far as the application systems are provided by central government and appropriate guidance are followed, problem in difficulties would be reduced.

Accordingly, the implementation of accrual accounting in Indonesian local government today is on its way. There are still a lot of things which need to be addressed and fixed to reach the desired outcome. Indeed, in these examined cases accounting reforms are taking place smoothly. However, the lack of human resources was found in the majority of departments and it is highly possible that this is faced by many other departments as well is. No pattern in the technical capabilities of the examined cases could sign the desperation of the actors perspective since they were confused in defining their competencies. Alongside this, the role of the leaders in motivating their staff and persuading them of the value of reform needs to be restyled. Being a leader is not merely a responsibility to run errands to meet regulatory demands, more than that, it is having the ability as a guardian and guide for behaving well and enhancing staff satisfaction as necessary to direct staff towards achieving the goal of reform. By doing that, staff will feel comfortable and it will lead to the improvement of the quality of performance.

In conclusion, the findings in this research are relatively new in the cases of Indonesian studies. Based on the researcher observation, the approach that was used here (i.e., the utilization of the archetype theory to define the outcome and intra-organizational dynamics) has not been used to examine the Indonesian cases. However, comparing with previous literature, Liguori (2012b) has used this approach to investigate the Italian and Canadian cases recently and this research repliclate and specified the Liguori (2012b) study. This research is still far from perfect. There are many limitations within this study. First, with regard to the relevance of the 
data, the number of interviewees in this study may be said to be minimal considering the huge scope of the government of Indonesia. By using a similar method, referring to Liguori (2012b) and Greenwood and Hinings (1996) further research can expand the amount of participants and extend organizations' criteria or investigate a higher level of government so that a broader scope of research will provide more relevant variations on the findings which represent the change process in Indonesia. Furthermore, regarding the scope of the main case, in this study, the phenomenon is discussed primarily on the implementation of accrual accounting. Further research could develop more cases related to other aspect of the NPM reform in Indonesia and compared it to other countries with different type of reforms referred to Zhang (2014).

\section{REFERENCES}

Amriani, T. N. (2014). 'Menyongsong Penerapan Akuntansi Pemerintahan Berbasis Akrual [Welcoming the Adoption of Accrual Based Government Accounting]', Available at: http://www.bpppk.kemenkeu.go.id/ berita-makassar/19410-menyongsong-penerapan-akuntansi-pemerintahan-berbasis-akrual (Accessed: 16 March 2016)

Analyst Bureau of Budgetary (2015) 'Review of the preparation of the Accrual Accounting Implementation', Jakarta: Indonesian Parliament.

Andrews, R., and Van de Walle, S. (2013). 'New public management and citizens' perceptions of local service efficiency, responsiveness, equity and effectiveness', Public Management Review, 15(5): 762-783.

Anessi-Pessina, E., Nasi, G., and Steccolini, I. (2008). 'Accounting reforms: Determinants of local governments' choices', Financial Accountability \& Management, 24(3): 321-342.

Baker, R.O.N., and Rennie, M.D. (2006). 'Forces Leading to the Adoption of Accrual Accounting by the Canadian Federal Government: An Institutional Perspective', Canadian Accounting Perspectives, 5(1): 83-112.

Baswedan, A. (2007). 'Indonesia politics in 2007: The presidency, local elections and the future of democracy', Bulletin of Indonesian Economics Studies, 43(3): 323-40.

Brock, D.M. (2006). 'The changing professional organization: A review of competing archetypes', International Journal of Management Reviews, 8(3): 157-174.

Brown, T.L. and Potoski, M. (2003). 'Transaction Costs and Institutional Explanations for Government Service Production Decisions', Journal of Public Administration Research and Theory, 13(4): 441-68.

Bruns, H.J. (2014). 'Accounting change and value creation in public services-Do relational archetypes make a difference in improving public service performance?', Critical Perspectives on Accounting, 25(4): 339367.

Burns, J. (2000). 'The dynamics of accounting change inter-play between new practices, routines, institutions, power and politics', Accounting, auditing and accountability journal, 13(5): 566-596.

Burns, J., and Scapens, R., (2000). 'Conceptualizing management accounting change: an institutional framework', Management Accounting Research, 11(1), 3-25.

Burns, J., Ezzamel, M. and Scapens, R. (1999). 'Management accounting change in the UK', Management 
Accounting, 77(3): 28-30

Burton, D. (2000). 'The Use of Case Studies in Social Science Research', in Dawn Burton (ed.), Research Training for Social Scientist, London, SAGE Publications: 210-225.

Carlin, T.M. (2005). 'Debating the impact of accrual accounting and reporting in the public sector', Financial Accountability and Management, 21(3): 309-36

Christensen, M., and Yoshimi, H. (2003) 'Public sector performance reporting: New public management and contingency theory insights' Government Auditing Review, 10(3): 71-83.

Christiaens, J., and Van Peteghem, V. (2007). 'Governmental accounting reform: evolution of the implementation in Flemish municipalities', Financial Accountability \& Management, 23(4): 375-399.

Christiaens, J., Reyniers, B., and Rolle, C. (2010). 'Impact of IPSAS on Reforming Governmental Financial Information Systems: A Comparative Study', International Review of Administrative Science. 76(3): 537554.

Collier, P.M. (2001). 'The Power of Accounting: A Field Study of Local Financial Management in a Police Force', Management Accounting Research, 12(4): 465-86.

Collis, J., Hussey, R., and Hussey, J. (2003). Business Research: A Practical Guide to Undergraduate and Postgraduate Students, 2nd edn., Basingstoke: Palgrave Macmillan.

Dillard, J.F., Rigsby, J.T., and Goodman, C. (2004). 'The making and remaking of organization context: duality and the institutionalization process', Accounting, Auditing and Accountability Journal, 17(4): 506-542.

DiMaggio, P., and Powell, W. (1983). 'The Iron Revisited: Institutional Isomorphism and Collective Rationality in Organizational Fields', American Sociological Review, 48(2): 147-160.

DiMaggio, P., and Powell, W. (1991). 'Introduction', in W. Powell and P. DiMaggio (eds.), The New Institutionalism in Organizational Analysis, Chicago, The University of Chicago Press: 1-38

Djamhuri, A. (2009). 'A case study of governmental accounting and budgeting Reform at local authority in Indonesia: an institutionalist perspective', Doctoral research, Semarang: Universitas Semarang.

Ellwood, S. (2002). 'The financial reporting (r)evoluton in the UK public sector', Journal of Public Budgeting, Accounting \& Financial Management, 14(4): 565-94.

Ezzamel, M., Robson, K., Stapleton, P., and McLean, C. (2007). 'Discourse and institutional change:'giving accounts' and accountability, Management Accounting Research, 18(2): 150-171.

Greenwood, R., and Hinings, C.R. (1988) 'Organizational design types, tracks and the dynamics of strategic change', Organization studies, 9(3): 293-316.

Greenwood, R., and Hinings, C.R. (1993). 'Understanding Strategic Change: The Contribution of Archetypes', The Academy of Management Journal, 36(5): 1052-81.

Greenwood, R., and Hinings, C.R. (1996) 'Understanding radical organizational change: Bringing together the old and the new institutionalism', The Academy of Management Review, 21(4): 1022-1054.

Guthrie, J. (1998). 'Application of accrual accounting in the Australian public sector-rhetoric or reality', Financial Accountability and Management, 4(1): 1-19.

Harun (2007). 'Obstacles to public sector accounting reform in Indonesia', Bulletin of Indonesian Economic 
Studies, 43(3):365-376.

Harun, H., and Kamase, H.P. (2012). 'Accounting change and institutional capacity: The case of a provincial government in Indonesia', Australasian Accounting Business \& Finance Journal, 6(2): 35-50.

Harun, H., Van-Peursem, K., and Eggleton, I.R. (2015). 'Indonesian public sector accounting reforms: dialogic aspirations a step too far?', Accounting, Auditing \& Accountability Journal, 28(5): 706-738.

Hassan, M.M. (2013). 'Debates on accrual accounting in the public sector: A discrepancy between practitioners and academicians', In Seventh Asia Pacific interdisciplinary research in accounting conference-APIRA Kobe.

Hassan, M.M. (2015). 'Transformation to More-Accrual-Based Accounting Practices in Indonesian Government', Journal of International Business Research, 14(1): 139-165.

Hinings, C.R., and Greenwood, R. (1988). The Tracks and Dynamics of Strategic Change, Oxford: Basil Blackwell Ltd.

Hood, C. (1991). 'A Public Management for All Seasons?', Public Administration, 69(1): 3-19.

Hood, C. (1995). 'The "New Public Management" in the 1980s: variations on a theme', Accounting, organizations and society, 20(2): 93-109.

Hyndman, N., and Connolly, C. (2011). 'Accruals accounting in the public sector: A road not always taken', Management Accounting Research, 22(1): 36-45.

Ika, S. R., and Widagdo, A. K. (2013). 'Transitioning from cash basis to full accrual basis of indonesian public sector: obstacles and recent progresses', Efektif Jurnal Bisnis dan Ekonomi, 4(1): 48-61

King, D.Y. (2003). Half-Hearted Reform: Electoral Institutions and the Struggle for Democracy in Indonesia, New York: Praeger Publishers.

Kirkpatrick, I., and Ackroyd, S. (2003). 'Archetype theory and the changing professional organization: a critique and alternative', Organization, 10(4): 731-750.

Kristiansen, S., Dwiyanto, A., Pramusinto, A., and Putranto E. A. (2009). 'Public Sector Reform and Financial Transparency: Experiences from Indonesia District', Contemporary Southeast Asia: A Journal of International and Strategic Affair, 31(1): 64-87.

Kusuma, R.S., (2013). 'Analisis Kesiapan Pemerintah Dalam Menerapkan Standar Akuntansi Pemerintah Berbasis Akrual [Analysis of Government Preparedness in Implementing Accrual Based Government Accounting Standards]', Skripsi, Jember: Universitas Jember.

Lane, J.E. (2000). New Public Management: An Introduction (1), London: Routledge.

Langelo, F., Saerang, D.P.E., and Alexander, S.W. (2015). 'Analisis penerapan standar akuntansi pemerintahan berbasis akrual dalam penyajian laporan keuangan pada Pemerintah Kota Bitung [Analysis of the implementation of accrual based government accounting standards in preparing financial statements in Bitung City Government],' Jurnal Riset Ekonomi, Manajemen, Bisnis dan Akuntansi [Journal of Economic, Management, Business and Accounting Research], 3(1): 1-8.

Lapsley, I. (1999). 'Accounting and the new public management: instruments of substantive efficiency or a rationalising modernity?', Financial Accountability and Management, 15(3-4): 201-207. 
Lapsley, I., and Pallot, J. (2000), 'Accounting, management and organizational change: a comparative study of local government', Management Accounting Research, 11: 213-22.

Lapsley, I., Mussari, R., and Paulsson, G. (2009). 'On the Adoption of Accrual Accounting in the Public Sector: A Self Evident and Problematic Reform', European Accounting Review, 18(4): 719-723.

Liguori, M. (2012a). 'The Supremacy of the Sequence: Key Elements and Dimensions in the Process of Change', Organization Studies, 33(4):507-39.

Liguori, M. (2012b).'Radical change, accounting and public sector reforms: a comparison of Italian and Canadian municipalities', Financial Accountability and Management, 28(4): 437-463.

Liguori, M., and Steccolini, I. (2012). 'Accounting change: explaining the outcomes, interpreting the process', Accounting, Auditing and Accountability Journal, 25(1): 27-70.

Liguori, M., Sicilia, M., and Steccolini, I. (2009). 'Politicians versus managers: roles and interactions in accounting cycles', International Journal of Public Sector Management, 22(4): 310-323.

Lukas, S. (1974). Power: A Radical View, Macmillan: London

Ma, Y., and Tayles, M. (2009). 'On the emergence of strategic management accounting: An institutional perspective', Accounting and Business Research, 39(5): 473-495.

Malhotra, M., and Hinings, C. R. (2005). 'Processes of radical organizational change: Transformation through sedimentation'. First Organization Studies Summer Workshop on Theorizing Process in Organizational Research in Santorini June 2005.

Malsch, B., and Gendron, Y. (2013). 'Re-theorizing change: Institutional experimentation and the struggle for domination in the field of public accounting', Journal of Management Studies, 50(5): 870-899.

McLeod, R.H., and Harun, H. (2014). 'Public Sector Accounting Reform at Local Government Level in Indonesia', Financial Accountability \& Management, 30(2), 238-258.

McNulty, T., and Ferlie, E. (2004). 'Process transformation: Limitations to radical organizational change within public service organizations', Organization studies,25(8), 1389-1412.

Mir, M., and Sutiyono, W. (2013).'Public Sector Financial Management Reform: A Case Study of Local Government Agencies in Indonesia', Australasian Accounting Business \& Finance Journal, 7(4), 97.

Mu'am, A. (2015). 'Basis akrual dalam akuntansi pemerintah di Indonesia [Accrual base in Indonesian government accounting]', Jurnal Lingkar Widyaiswara, 2(1): 38-46.

Nor-Aziah, A.K., and Scapens, R.W. (2007), 'Corporation and Accounting Change: The Role of Accounting and Accountants in a Malaysian Public Utility', Management Accounting Research, 18(2): 209-247.

Oliver, C. (1991). 'Strategic Responses to Institutional Processes', The Academy of Management Review, 16(1): 145-179.

Patton, M. Q. (2001). Qualitative evaluation and research methods, 3rd edn., Newbury Park: Sage Publication.

Patton, M. Q. (2002). Qualitative research and evaluation methods, 3rd edn., Thousand Oaks: Sage Publications.

Paulsson, G. (2006). 'Accrual Accounting In The Public Sector: Experiences From The Central Government In Sweden', Financial Accountability and Management, 22(1): 47-62.

Pfeffer, J. (1981). Power in Organizations, Boston: Pitman. 
Pinnington, A., and Morris, T. (2003). 'Archetype change in professional organizations: Survey evidence from large law firms', British Journal of Management, 14(1): 85-99.

Powell, W.W., and DiMaggio, P.J. (1991). The new institutionalism in organizational analysis, Chicago: University of Chicago Press.

Pozzoli, M., and Ranucci, S. (2013). 'The Process of Implementing the Accounting Harmonisation In The Italian Local Governments: The Case of Prato', International Journal of Business Research and Development, 2(3): 1-18.

Prasojo, E., and Kurniawan, T. (2008). Reformasi Birokrasi dan Good Governance: Kasus Best Practices dari Sejumlah Daerah di Indonesia [Reforms and Good Governance: Best Practices Case of Indonesian Regions]. Dipresentasikan dalam The 5th International Symposiumof Journal Antropolgi Indonesia.

Ribeiro, J.A., and Scapens, R.W. (2006). 'Institutional theories in management accounting change: contributions, issues and paths for development', Qualitative Research in Accounting \& Management, 3(2): 94-111.

Ritchie, J., and Spencer, L. (2002) 'Qualitative data analysis for applied policy research', in A. Bryman and R.G. Burgess (eds.), Analyzing qualitative data, New York, Routledge: 173-194.

Robinson, M. (1998). 'Accrual accounting and the efficiency of the core public sector', Financial Accountability and Management, 14(1): 21-37.

Sari, D.P. and Putra, H.S. (2012). 'Menelisik akuntansi pemerintahan berbasis akrual [Exploring the accrual base in government accounting]', Jurnal Ekonomi Akuntansi Dan Manajemen [Journal of Economic Accounting and Management], 11(2): 33-56.

Seymour, R. and Turner, S. (2002). 'Otonomi Daerah (regional autonomy): Indonesia's decentralization experiment', New Zealand Journal of Asian Studies, 4(2): 33-51.

Shonhadji, N. (2010). 'Accrual accounting \& financial reporting in the public sector to enhance accountability and transparency (Reframing Implementation in Indonesia)', Ekuitas, 14(1): 22-38.

Simanjuntak, B.H. (2005). 'Menyongsong Era Baru Akuntansi Pemerintahan di Indonesia [Welcoming the New Era of Government Accounting in Indonesia]', Jurnal Akuntansi Pemerintah [Government Accounting Journal], 1(1): 1-15.

Strauss, A., and Corbin, J. (1998). Basics of qualitative research, Thousand Oaks, CA: Sage Publications.

Symon, G., and Cassel, C. (1998). Qualitative methods and analysis in organizational research, Thousand Oaks, CA: Sage Publications.

Ter Bogt, H. J. (2008). 'Management accounting change and new public management in local government: a reassessment of ambitions and results - an institutionalist approach to accounting change in the Dutch public sector', Financial Accountability \& Management, 24(3): 209-241.

Ter Bogt, H. J., and Van Helden, G. J. (2000). 'Accounting change in Dutch government: exploring the gap between expectations and realizations', Management Accounting Research, 11(2): 263-279.

Tsamenyi, M., Cullen, J., and González, J. M. G. (2006). 'Changes in accounting and financial information system in a Spanish electricity company: A new institutional theory analysis', Management Accounting Research, 17(4): 409-432. 
Verhoest, K., Verschuere, B., and Bouckaert, G. (2007). 'Pressure, Legitimacy, and Innovative Behavior by Public rganizations,' Governance: An International Journal of Policy, Administration, and Institutions, 20(3): 469497.

Wijaya, I.F. (2011). 'The Adoption of IPSASs in Developing Countries: A Case Study of Indonesia', Research, Birmingham: University of Birmingham.

Yin, R.K. (2003). Case study research: Design and Methods, $3^{\text {rd }}$ edn, Thousand Oaks, CA: Sage Publications.

Zhang, K. (2014). 'The research on the Accounting and Public Sector reform at Chinese local government level', Research, Belfast: Queens University Belfast.

Laws and Regulations

Law number 17/2003 on State Finance of Article 36 paragraph (1).

Law number 1/2004 on State Treasury of Article 70 paragraph (2).

Government Regulation number 24/2005 on Governmental Accounting Standards.

Government Regulation number 71/2010 on Governmental Accounting Standards.

Minister of Finance Decree number 5/2011 on Guidelines to Governmental Accounting System.

Indische Comptabiliteitswet (ICW) Staadsblaad 1925 Number 448 on State Treasury.

Minister of Home Affairs Decree number 64/2013 on The Application of Accrual-Based Government Accounting

Standards in Local Government.

Official Reports:

State Audit Board (2015). 'Ikhtisar Hasil Pemeriksaan Semester I and II tahun 2015 [Overview of the $1^{\text {st }}$ and $2^{\text {nd }}$ Semester Audit Results in 2015]', Jakarta: the State Audit Board of Indonesia.

The World Bank (1988). Staff Appraisal Report Indonesia: Accountancy Development Project 


\section{Attachment}

Table 1

Intra-organizational Dynamics Configurations

\begin{tabular}{|c|c|c|c|c|c|c|}
\hline & $\begin{array}{l}\text { Onion Regency } \\
\text { Environment }\end{array}$ & $\begin{array}{l}\text { Onion Regency } \\
\text { Social Service }\end{array}$ & $\begin{array}{l}\text { Onion } \\
\text { Regency Public } \\
\text { Infrastructure }\end{array}$ & $\begin{array}{l}\text { Egg Regency } \\
\text { Environment }\end{array}$ & $\begin{array}{l}\text { Egg Regency } \\
\text { Social Service }\end{array}$ & $\begin{array}{l}\text { Egg Regency } \\
\text { Public } \\
\text { Infrastructure }\end{array}$ \\
\hline $\begin{array}{l}\text { Outcome of } \\
\text { Change }\end{array}$ & Radical & Radical & Incremental & Incremental & Incremental & Incremental \\
\hline \multicolumn{7}{|c|}{ Intra-organizational Dynamics } \\
\hline Interest & $\begin{array}{l}\text { Satisfaction } \\
\text { with the new } \\
\text { archetype }\end{array}$ & $\begin{array}{l}\text { Satisfaction with } \\
\text { the new archetype }\end{array}$ & $\begin{array}{l}\text { Neither } \\
\text { Satisfaction nor } \\
\text { dissatisfaction }\end{array}$ & $\begin{array}{l}\text { Dissatisfaction } \\
\text { with the new } \\
\text { Archetype }\end{array}$ & $\begin{array}{l}\text { Neither } \\
\text { Satisfaction } \\
\text { nor } \\
\text { dissatisfaction }\end{array}$ & $\begin{array}{l}\text { Dissatisfaction } \\
\text { with the new } \\
\text { Archetype }\end{array}$ \\
\hline $\begin{array}{l}\text { Value } \\
\text { Commitment }\end{array}$ & Reformative & Reformative & Status Quo & Indifferent & No pattern & No pattern \\
\hline $\begin{array}{l}\text { Power } \\
\text { Dependencies }\end{array}$ & Dispersed & Concentrated & Concentrated & Concentrated & Concentrated & Concentrated \\
\hline $\begin{array}{l}\text { Technical } \\
\text { Capabilities }\end{array}$ & No Pattern & No Pattern & No pattern & No pattern & No pattern & $\begin{array}{l}\text { Low and } \\
\text { concentrated }\end{array}$ \\
\hline $\begin{array}{l}\text { Managerial } \\
\text { Capabilities }\end{array}$ & $\begin{array}{l}\text { Transformational } \\
\text { and Symbolic }\end{array}$ & $\begin{array}{l}\text { Transformational } \\
\text { and Symbolic }\end{array}$ & $\begin{array}{l}\text { Transactional } \\
\text { and Symbolic }\end{array}$ & $\begin{array}{l}\text { Transformational } \\
\text { and Symbolic }\end{array}$ & $\begin{array}{l}\text { Transactional } \\
\text { and Symbolic }\end{array}$ & $\begin{array}{l}\text { Transformational } \\
\text { and symbolic }\end{array}$ \\
\hline
\end{tabular}

